\title{
Cardiac Manifestations in Patients with COVID-19: A Scoping Review
}

\section{Preferred Reporting Items for Systematic reviews and Meta-Analyses extension for Scoping Reviews (PRISMA-ScR) Checklist}

\begin{tabular}{|c|c|c|c|}
\hline SECTION & ITEM & PRISMA-ScR CHECKLIST ITEM & $\begin{array}{l}\text { REPORTED } \\
\text { ON PAGE \# }\end{array}$ \\
\hline \multicolumn{4}{|l|}{ TITLE } \\
\hline Title & 1 & Identify the report as a scoping review. & 1 \\
\hline \multicolumn{4}{|l|}{ ABSTRACT } \\
\hline $\begin{array}{l}\text { Structured } \\
\text { summary }\end{array}$ & 2 & $\begin{array}{l}\text { Provide a structured summary that includes (as } \\
\text { applicable): background, objectives, eligibility criteria, } \\
\text { sources of evidence, charting methods, results, and } \\
\text { conclusions that relate to the review questions and } \\
\text { objectives. }\end{array}$ & 2,3 \\
\hline \multicolumn{4}{|l|}{ INTRODUCTION } \\
\hline Rationale & 3 & $\begin{array}{l}\text { Describe the rationale for the review in the context of } \\
\text { what is already known. Explain why the review } \\
\text { questions/objectives lend themselves to a scoping } \\
\text { review approach. }\end{array}$ & 5 \\
\hline Objectives & 4 & $\begin{array}{l}\text { Provide an explicit statement of the questions and } \\
\text { objectives being addressed with reference to their key } \\
\text { elements (e.g., population or participants, concepts, } \\
\text { and context) or other relevant key elements used to } \\
\text { conceptualize the review questions and/or objectives. }\end{array}$ & 5 \\
\hline \multicolumn{4}{|l|}{ METHODS } \\
\hline $\begin{array}{l}\text { Protocol and } \\
\text { registration }\end{array}$ & 5 & $\begin{array}{l}\text { Indicate whether a review protocol exists; state if and } \\
\text { where it can be accessed (e.g., a Web address); and if } \\
\text { available, provide registration information, including } \\
\text { the registration number. }\end{array}$ & 6 \\
\hline Eligibility criteria & 6 & $\begin{array}{l}\text { Specify characteristics of the sources of evidence } \\
\text { used as eligibility criteria (e.g., years considered, } \\
\text { language, and publication status), and provide a } \\
\text { rationale. }\end{array}$ & 6,7 \\
\hline $\begin{array}{l}\text { Information } \\
\text { sources* }^{*}\end{array}$ & 7 & $\begin{array}{l}\text { Describe all information sources in the search (e.g., } \\
\text { databases with dates of coverage and contact with } \\
\text { authors to identify additional sources), as well as the } \\
\text { date the most recent search was executed. }\end{array}$ & 6,7 \\
\hline Search & 8 & $\begin{array}{l}\text { Present the full electronic search strategy for at least } 1 \\
\text { database, including any limits used, such that it could } \\
\text { be repeated. }\end{array}$ & 6,7 \\
\hline $\begin{array}{l}\text { Selection of } \\
\text { sources of } \\
\text { evidence† }\end{array}$ & 9 & $\begin{array}{l}\text { State the process for selecting sources of evidence } \\
\text { (i.e., screening and eligibility) included in the scoping } \\
\text { review. }\end{array}$ & 6,7 \\
\hline $\begin{array}{l}\text { Data charting } \\
\text { process }\end{array}$ & 10 & $\begin{array}{l}\text { Describe the methods of charting data from the } \\
\text { included sources of evidence (e.g., calibrated forms or } \\
\text { forms that have been tested by the team before their } \\
\text { use, and whether data charting was done } \\
\text { independently or in duplicate) and any processes for } \\
\text { obtaining and confirming data from investigators. }\end{array}$ & 6,7 \\
\hline Data items & 11 & $\begin{array}{l}\text { List and define all variables for which data were } \\
\text { sought and any assumptions and simplifications made. }\end{array}$ & 6,7 \\
\hline
\end{tabular}




\begin{tabular}{|c|c|c|c|}
\hline SECTION & ITEM & PRISMA-ScR CHECKLIST ITEM & $\begin{array}{l}\text { REPORTED } \\
\text { ON PAGE \# }\end{array}$ \\
\hline $\begin{array}{l}\text { Critical appraisal of } \\
\text { individual sources } \\
\text { of evidence§ }\end{array}$ & 12 & $\begin{array}{l}\text { If done, provide a rationale for conducting a critical } \\
\text { appraisal of included sources of evidence; describe } \\
\text { the methods used and how this information was used } \\
\text { in any data synthesis (if appropriate). }\end{array}$ & 8 \\
\hline $\begin{array}{l}\text { Synthesis of } \\
\text { results }\end{array}$ & 13 & $\begin{array}{l}\text { Describe the methods of handling and summarizing } \\
\text { the data that were charted. }\end{array}$ & 8 \\
\hline \multicolumn{4}{|l|}{ RESULTS } \\
\hline $\begin{array}{l}\text { Selection of } \\
\text { sources of } \\
\text { evidence }\end{array}$ & 14 & $\begin{array}{l}\text { Give numbers of sources of evidence screened, } \\
\text { assessed for eligibility, and included in the review, with } \\
\text { reasons for exclusions at each stage, ideally using a } \\
\text { flow diagram. }\end{array}$ & 8 \\
\hline $\begin{array}{l}\text { Characteristics of } \\
\text { sources of } \\
\text { evidence }\end{array}$ & 15 & $\begin{array}{l}\text { For each source of evidence, present characteristics } \\
\text { for which data were charted and provide the citations. }\end{array}$ & 9 \\
\hline $\begin{array}{l}\text { Critical appraisal } \\
\text { within sources of } \\
\text { evidence }\end{array}$ & 16 & $\begin{array}{l}\text { If done, present data on critical appraisal of included } \\
\text { sources of evidence (see item 12). }\end{array}$ & 9 \\
\hline $\begin{array}{l}\text { Results of } \\
\text { individual sources } \\
\text { of evidence }\end{array}$ & 17 & $\begin{array}{l}\text { For each included source of evidence, present the } \\
\text { relevant data that were charted that relate to the } \\
\text { review questions and objectives. }\end{array}$ & $9-21$ \\
\hline $\begin{array}{l}\text { Synthesis of } \\
\text { results }\end{array}$ & 18 & $\begin{array}{l}\text { Summarize and/or present the charting results as they } \\
\text { relate to the review questions and objectives. }\end{array}$ & $9-21$ \\
\hline \multicolumn{4}{|l|}{ DISCUSSION } \\
\hline $\begin{array}{l}\text { Summary of } \\
\text { evidence }\end{array}$ & 19 & $\begin{array}{l}\text { Summarize the main results (including an overview of } \\
\text { concepts, themes, and types of evidence available), } \\
\text { link to the review questions and objectives, and } \\
\text { consider the relevance to key groups. }\end{array}$ & $21-26$ \\
\hline Limitations & 20 & Discuss the limitations of the scoping review process. & 26 \\
\hline Conclusions & 21 & $\begin{array}{l}\text { Provide a general interpretation of the results with } \\
\text { respect to the review questions and objectives, as well } \\
\text { as potential implications and/or next steps. }\end{array}$ & 27 \\
\hline \multicolumn{4}{|l|}{ FUNDING } \\
\hline Funding & 22 & $\begin{array}{l}\text { Describe sources of funding for the included sources } \\
\text { of evidence, as well as sources of funding for the } \\
\text { scoping review. Describe the role of the funders of the } \\
\text { scoping review. }\end{array}$ & $\begin{array}{l}\text { Online } \\
\text { submission }\end{array}$ \\
\hline \multicolumn{4}{|c|}{$\begin{array}{l}\text { JBI = Joanna Briggs Institute; PRISMA-ScR = Preferred Reporting Items for Systematic reviews and Meta-Analyses } \\
\text { extension for Scoping Reviews. } \\
\text { *Where sources of evidence (see second footnote) are compiled from, such as bibliographic databases, social media } \\
\text { platforms, and Web sites. } \\
\dagger \text { A more inclusive/heterogeneous term used to account for the different types of evidence or data sources (e.g., } \\
\text { quantitative and/or qualitative research, expert opinion, and policy documents) that may be eligible in a scoping } \\
\text { review as opposed to only studies. This is not to be confused with information sources (see first footnote). } \\
\ddagger \text { The frameworks by Arksey and O'Malley (6) and Levac and colleagues }(7) \text { and the JBI guidance }(4,5) \text { refer to the } \\
\text { process of data extraction in a scoping review as data charting. } \\
\S \text { The process of systematically examining research evidence to assess its validity, results, and relevance before } \\
\text { using it to inform a decision. This term is used for items } 12 \text { and } 19 \text { instead of "risk of bias" (which is more applicable } \\
\text { to systematic reviews of interventions) to include and acknowledge the various sources of evidence that may be used } \\
\text { in a scoping review (e.g., quantitative and/or qualitative research, expert opinion, and policy document). }\end{array}$} \\
\hline
\end{tabular}

From: Tricco AC, Lillie E, Zarin W, O'Brien KK, Colquhoun H, Levac D, et al. PRISMA Extension for Scoping Reviews (PRISMAScR): Checklist and Explanation. Ann Intern Med. 2018;169:467-473. doi: 10.7326/M18-0850. 